\title{
EFEKTIVITAS METODE PEMBELAJARAN DARING (DALAM JARINGAN) PADA MATA KULIAH ASUHAN KEBIDANAN
}

\author{
${ }^{1)}$ Husna Farianti Amran, ${ }^{2)}$ Linda Suryani \\ ${ }^{1,2)}$ Program Studi Sarjana Kebidanan, STIKes Payung Negeri Pekanbaru \\ J1. Tamtama No 6 Labuh Baru. Pekanbaru-Riau-Indonesia \\ Email: husna.farianti@payungnegeri.ac.id linda.suryani@payungnegeri.ac.id
}

\section{Kata Kunci:}

Efektivitas, Metode daring, Hasil belajar

Keywords:

Effectiveness, online learning methods, student learning outcomes

\section{Info Artikel}

Tanggal dikirim: 12-06-2021

Tanggal direvisi: $21-06-2021$

Tanggal diterima: 22-07-2021 DOI Artikel:

10.36341/jomis.v5i2.1870

Creative Commons Attribution-

NonCommercial-ShareAlike 4.0 International License.

\section{ABSTRAK}

Pandemi Covid-19 memberikan dampak bagi dunia pendidikan. Untuk pencegahan penyebaran covid 19 pemerintah mengeluarkan kebijakan untuk meliburkan seluruh lembaga pendidikan. Kegiatan pembelajaran dilakukan dengan Pembelajaran Jarak Jauh atau disebut pembelajaran daring. Hal ini menuntut kemampuan dosen dan mahasiswa untuk dapat menggunakan teknologi informasi secara efektif agar tujuan pembelajaran dapat tercapai. Tujuan penelitian ini mengetahui efektivitas metode pembelajaran daring pada matakuliah asuhan kebidanan. Penelitian ini merupakan penelitian kuantitaif dengan desain penelitian analitik coss sectional. Populasi seluruh mahasiswi program studi S1 Kebidanan STIKes Payung Negeri Pekanbaru yang berjumlah 36 orang, seluruh populasi dijadikan objek penelitian. Penelitian dilakukan bulan Maret - Juni 2021. Pengumpulan data menggunakan kuesioner dan dianalisa secara univariate dan bivariate. Hasil penelitian diperoleh efektivitas metode pembelajaran daring berada pada kategori efektif yaitu 58,3\% (21 Responden), Aspek keefektifan metode pembelajran daring adalah digunakannya media yang sesuai $72,3 \%$ (26 Responden), Hasil belajar mahasiswa berada pada kategori Baik yaitu 58,3\% (21 Responden) dan terdapat hubungan efektifitas metode pembelajran Daring dengan hasil belajar mahasiswa $(r=0,509)$ dengan tingkat keeratan sedang yaitu $t=3,448$. Diharapkan kepada Dosen selaku tenaga pendidik dapat memperhatikan aspek-aspek seperti: menggunakan media pembelajaran yang sesuai, Strategi pembelajaran (Instructional Strategy) yang baik, Aktivitas pembelajaran yang variatif, dan Sumber Belajar (Learning Resources) yang luas, sehingga pembelajaran daring dapat dilaksanakan secara efektif dan tujuan pembelajaran dapat tercapai yang dapat dilihat dari hasil belajar mahasiswa yang baik.

\section{ABSTRACT}

The Covid-19 pandemic has had an impact on the world of education. To prevent the spread of COVID-19, the government issued a policy to close all educational institutions. Learning activities are carried out by Distance Learning or called online learning. This requires the ability of lecturers and students to be able to use information technology effectively so that learning objectives can be achieved. This study aims to determine the effectiveness of online learning methods on student learning outcomes. This type of research is quantitative with an analytic design with a coss sectional approach. The population of all students of the program study S1 Midwifery STIKes Payung Negeri Pekanbaru, which amounted to 36 people, the entire population was used as the object of research. The study was conducted in MarchJune 2021. Data were collected using a questionnaire and analyzed by univariate and bivariate. The results obtained that the effectiveness of online learning methods is in the effective category $58.3 \%$ (21 respondents), the aspect of the effectiveness of online learning methods is the use of appropriate media $72.3 \%$ (26 respondents), student learning outcomes are in the Good category 58, 3\% (21 respondents) and there is a relationship between the effectiveness of online learning methods and student learning outcomes ( $r=0.509)$ with a moderate level $t=3.448$. It is expected that lecturers as educators can pay attention to aspects such as: using appropriate learning media, good instructional strategies, varied learning activities, and extensive learning resources, so that online learning can be carried out effectively. and learning objectives can be achieved which can be seen from good student learning outcomes. 


\section{PENDAHULUAN}

Pendidikan tenaga kesehatan bertujuan menghasilkan tenaga kesehatan yang profesional yang memiliki kemampuan untuk bekerja secara mandiri, mampu mengembangkan diri dan beretika.[1]

Bidan salah satu tenaga kesehatan yang bertugas sangat penting dalam penurunan Angka Kematian Ibu dan Bayi serta peningkatan kesejahteraan masyarakat khususnya perempuan dan anak. Dalam memberikan pelayanan bidan harus mampu menghadapi perkembangan jaman, untuk itu kurikulum kebidanan dibuat dan dirancang guna menghasilkan seorang bidan yang mampu memberikan asuhan kebidanan sesuai dengan perkembangan ilmu pengetahuan dan teknologi dengan memanfaatkan IPTEK. Agar kurikulum tersebut dapat dilakukan dengan optimal diperlukan metode pembelajaran yang efektif sesuai dengan karakteristik mata kuliah. Metode Pembelajaran yang dapat dipilih untuk pelaksanaan pembelajaran pada mata kuliah meliputi metode pembelajaran yang mampu membuat mahasiswa berfikir secara aktif sehingga mahasiswa tidak hanya menerima informasi dari dosen saja melainkan mencari informasi dari berbagai sumber, sehingga tidak hanya kemampuan kognitif saja yang berkembang tetapi juga psikomotor dan afektif [2]

Masa pandemi Covid-19 memberikan dampak bagi seluruh lini kehidupan didunia termasuk dunia pendidikan khususnya di Indonesia. Pemerintah mengeluarkan kebijakan untuk meliburkan seluruh lembaga pendidikan yang ada di negeri ini, hal ini dilakukan guna pencegahan penularan covid-19 diberbagai lingkungan dan komunitas. Untuk meminimalisir ketertinggalan aktivitas pendidikan, pemerintah memberikan alternatif berupa penyelenggaraan sekolah atau pembelajaran jarak jauh atau yang biasa disebut dengan pembelajaran daring dengan memanfaatkan berbagai platform digital atau e-learning sebagi media utama. [3] Pembelajaran daring merupakan pendidikan formal yang diselenggarakan oleh sekolah yang peserta didik dan instrukturnya (guru/dosen) berada dilokasi terpisah sehingga memerlukan sistem telekomunikasi interaktif untuk menghubungkan keduanya dan berbagai sumber daya yang diperlukan didalamnya. Pembelajaran daring dapat dilakukan dari mana dan kapan saja tergantung ketersediaan alat pendukung yang digunakan. [4]

Kebijakan pemerintah ini dilegalkan melalui Surat Edaran Menteri Pendidikan dan Kebudayaan Republik Indonesia Nomor 4 Tahun 2020 tentang Pelaksanaan Kebijakan Pendidikan dalam Masa Darurat Penyebaran Covid-19. Kemampuan menggunakan dan memanfaat berbagai jenis teknologi pembelajaran menuntut pendidik dan peserta didik bergerak kearah kemajuan digitalisasi pendidikan secara bersamaan. Realita ini tentu menjadi tantangan tersendiri, khususnya bagi guru dan dosen untuk senantiasa belajar mengoptimalkan sistem pembelajaran digital untuk dapat berinteraksi dengan peserta didik dari rumah masing-masing. Jenis media digital yang dapat dimanfaatkan dalam pembelajaran daring cenderung beragam, seperti WhatsApp Group (WAG), You-Tube, Zoom Meeting, Edmodo, Google Classroom, Google Meet, dan sebagainya. Sistem pembelajaran daring membuat berbagai jenis aktivitas, tugas pembelajaran, waktu pembelajaran, dapat dibuat secara bervariasi dan fleksibel sesuai keadaan dan kemampuan guru, dosen, siswa maupun mahasiswa dengan tanpa mempersulit kondisi kedua belah pihak. [3]

Implementasi pembelajaran daring ini menghadapi sejumlah kendala di lapangan. Pertama, dari sisi budaya pembelajaran, masih banyak dosen maupun mahasiswa yang belum terbiasa menggunakan sistem pembelajaran daring, kedua, pembelajaran daring menghadapi kendala jaringan internet, ketiga, belum semua perguruan tinggi memiliki sistem pembelajaran daring, baik secara infrastruktur maupun platform pembelajaran, keempat, pendidikan daring membutuhkan jaringan internet yang seringkali biayanya mahal 
sehingga memberatkan kalangan mahasiswa. [5]

Hasil penelitian Ratnanengsih, Prapitasari R tahun 2020 tentang pembelajaran daring partograf pada mata kuliah asuhan kebidanan persalinan masa pandemi didapatkan hasil terdapat perbedaan hasil belajar daring partograf manual dan partograf berbasis aplikasi, dengan pengetahuan $\mathrm{p}=0,000$ dan keterampilan $\mathrm{p}=0,004$. [6]

Penelitian yang sama juga dilakukan oleh Sundayana I tahun 2020 tentang Efektivitas Pembelajaran Online Pada Pendidikan Tinggi Kesehatan Di Masa Pandemi Covid-19 didapatkan hasil sebagain besar responden berasal dari prodi perawat $71.05 \%$, menggunakan hotspot/kuota handphone $84.87 \%$, tidak mengetahui tujuan mata kuliah $88.08 \%$, persentase pemanahaman materi $50 \%$ sebesar $44.74 \%$, perlu video pada setiap pembelajaran $84.21 \%$, dan pembelajaran online dianggap tidak efektivit sebasar $51.32 \%$, sehingga dapat ditarik kesimpulan efektifitas online berhubungan dengan tujuan mata kuliah, dan persentase pemahaman materi yang diberikan. [7]

Berdasarkan dari keinginan untuk menghasilkan lulusan sarjana kebidanan yang mampu menggunakan dan memanfaatkan teknologi informasi dalam menunjang dunia pendidikan. Tujuan penelitian ini adalah untuk mengetahui efektivitas metode pembelajaran daring (dalam jaringan) pada mata kuliah asuhan kebidanan di STIKES Payung Negeri Pekanbaru

\section{TINJAUAN PUSTAKA}

Efektivitas merupakan hubungan antara output dengan tujuan, semakin besar kontribusi (sumbangan) output terhadap pencapaian tujuan, maka semakin efektif organisasi, program atau kegiatan". Efektivitas berfokus pada outcome (hasil), program atau kegiatan yang dinilai efektif apabila output yang dihasilkan dapat memenuhi tujuan yang diharapkan atau dikatakan spending wisely. [8] Efektifnya hasil belajar apabila terjadi perubahan yang positif terhadap tingkah laku mahasiswa dan tercapainya tujuan pembelajaran yang telah ditetapkan. Cara mewujudkan pembelajaran yang efektif, di antaranya: 1) Pendidik membuat persiapan pengajaran yang sistematis, 2) Penyampaian materi yang bervariasi, 3) Waktu pembelajaran yang efektif, 4) pendidik dan peserta didik memiliki motivasi yang tinggi, 5) adanya hubungan interaktif yang baik antara pendidik dan peserta didik. [9]

Efektivitas suatu pembelajaran tidak terlepas dari peran pendidik, kondisi pembelajaran, peserta didik, dan lingkungan belajar.[10]

Pembelajaran daring merupakan pendidikan yang diselenggarakan oleh sekolah dimana siswa dan guru berada dilokasi yang berbeda sehingga memerlukan sistem komunikasi interaktif untuk menghubungkan keduanya dan berbagai sumber daya yang dibutuhkan didalamnya. Manfaat dari pembelajaran daring, antara lain: 1) Membangun komunikasi dan diskusi efisien antara siswa dan guru, 2) Memudahkan siswa berinteraksi dan berdiskusi antar sesama siswa, 3) Memudahkan interaksi antara guru, siswa dan oang tua siswa, 4) Sarana untuk ujian dan kuis, 5) Memudahkan guru memberikan materi kepada siswa baik berupa gambar dan video, 6) Memudahkan siswa mencari dan mengunduh bahan ajar, 7) Guru dapat membuat soal maupun kuis dimana saja dan kapan saja tanpa batas waktu. [4]

Kekurangan penggunaan pembelajaran daring antara lain:1) media yang dibutuhkan sangat beragam, sehingga sulit diterapkan jika sarana dan prasarana tidak mendukung, 2) fasilitas yang dimilikisiswa tidak setara, seperti komputer dan akses internet, 3) kurangnya pengetahuan publik tentang penggunaan teknologi, 4) kurangnya keterampilan dalam mempersiapkan dan menerapkan e-learning. [11]

Media yang bisa dimanfaatkan pada pembelajaran online antara lain google classroom, whatsapp group, zoom dan lain sebagainya. Penggunaan media tersebut sangat bermanfaat dalam menyampaikan materi secara tatap muka secara virtual, peserta didik dan pengajar dapat berinteraksi dengan baik serta adanya feed back antara peserta didik dan pengajar dalam pembelajaran sehingga pembelajaran lebih menyenangkan dan materi 
juga tersampaikan kepada peserta didik dengan baik dan dapat diserap dengan mudah [12]

Hasil belajar dapat berupa perubahan baik dari aspek kognitif, prikomotik, dan afektif yang dialami oleh seorang peserta didik. [9] sehinggan perubahan pada hasil belajar bukan hanya salah satu aspek potensi kemanusiaan saja melainkan perilaku secara keseluruhan. [13] Yang mempengaruhi proses dan hasil belajar antara lain: 1) Faktor dari dalam (Faktor fisiologis dan Faktor psikologis), 2) Faktor Ekstern (Faktor lingkungan, dan faktor instrumental) [14] Pembelajaran Daring yang dilaksanakan secara efektif oleh dosen dan mahasiswa akan memberikan capaian hasil belajar yang baik, untuk itu perlu diperhatikan aspek-aspek seperti dalam pelaksanaan pembelajaran dosen menggunakan media pembelajaran yang sesuai, Strategi pembelajaran (Instructional Strategy) yang baik, Aktivitas pembelajaran yang variatif, dan Sumber Belajar (Learning Resources) yang luas. [15]

Hasil penelitian Rusdiana.E dan Nugroho.A : 2020 menunjukkan perkuliahan dengan daring dan menggunakan bahan ajar yang praktis mudah difahami oleh mahasiswa, dan motivasi mahasiswa untuk mengikuti perkuliahan daring adalah tergolong tinggi (71\%).[16] Hasil penelitian Ratnanengsih, Prapitasari R tahun 2020 tentang pembelajaran daring partograf pada mata kuliah asuhan kebidanan persalinan masa pandemi didapatkan hasil terdapat perbedaan hasil belajar daring partograf manual dan partograf berbasis aplikasi, dengan pengetahuan $\mathrm{p}=0,000$ dan keterampilan $\mathrm{p}=0,004$. [6]

\section{METODE}

penelitian ini adalah penelitian kuantitatif dengan desain analitik cross sectional. Waktu penelitian dilakukan pada bulan Maret- Juni 2021. Populasi penelitian ini adalah seluruh mahasiswi Program Studi S1 Kebidanan STIKes Payung Negeri Pekanbaru tahun 2021 yang berjumlah 36 orang. Dan seluruh populasi dijadikan objek penelitian. Alat pengumpulan data menggunakan kuesioner. Analisa Data menggunakan analisa Univariate dan bivariate dengan menggunakan uji korelasi Rank-spearman

\section{HASIL DAN PEMBAHASAN \\ Hasil}

Berdasarkan analisis data secara univariat dan bivariate terhadap variable Efektifitas Metode Pembelajaran Daring (Dalam Jaringan) Pada Mata Kuliah Asuhan Kebidanan diperoleh hasil sebagai berikut.

Tabel 1

Distribusi Frekuensi Efektifitas Metode Pembelajaran Daring (Dalam Jaringan) Pada Mata Kuliah Asuhan Kebidanan

\begin{tabular}{llll}
\hline No & Kategori & Frekuensi & \% \\
\hline 1 & Efektif & 21 & 58,3 \\
2 & Cukup Efektif & 10 & 27,8 \\
3 & Kurang Efektif & 5 & 13,9 \\
\hline & Total & 36 & 100 \\
\hline
\end{tabular}

Berdasarkan tabel diketahui bahwa efektivitas metode Pembelajaran Daring (Dalam Jaringan) pada mata kuliah asuhan kebidanan $58,3 \%$ berada pada kategori efektif 
Tabel 2

Distribusi Frekuensi Responden Berdasarkan Aspek Keefektivan Metode Pembelajaran Daring (Dalam Jaringan) berdasarkan Kategori Efektivitas Pada Mata Kuliah Asuhan Kebidanan

\begin{tabular}{|c|c|c|c|c|c|c|c|c|}
\hline \multirow[t]{3}{*}{ Aspek } & \multicolumn{8}{|c|}{ Metode Pembelajaran Daring (Dalam Jaringan) } \\
\hline & \multicolumn{2}{|c|}{ Efektif } & \multicolumn{2}{|c|}{ Cukup Efektif } & \multicolumn{2}{|c|}{$\begin{array}{l}\text { Kurang } \\
\text { Efektif }\end{array}$} & \multicolumn{2}{|c|}{ Jumlah } \\
\hline & $\mathrm{n}$ & $\%$ & $\mathrm{n}$ & $\%$ & $\mathrm{n}$ & $\%$ & $\mathrm{n}$ & $\%$ \\
\hline Menggunakan Media yang Sesuai & 26 & 72,3 & 7 & 19,4 & 3 & 8,3 & 36 & 100 \\
\hline $\begin{array}{l}\text { Strategi Pembelajaran } \\
\text { (Instructional Strategy) yang baik }\end{array}$ & 17 & 47,2 & 13 & 36,1 & 6 & 16,7 & 36 & 100 \\
\hline Aktivitas Pembelajaran Variatif & 13 & 36,1 & 16 & 44,4 & 7 & 19,4 & 36 & 100 \\
\hline $\begin{array}{l}\text { Sumber Belajar (Learning } \\
\text { Resources) Luas }\end{array}$ & 21 & 58,3 & 15 & 41,7 & 0 & 0 & 36 & 100 \\
\hline
\end{tabular}

Berdsarakan tabel diatas diketahui bahwa aspek pelaksanaan metode Pembelajaran Daring (Dalam Jaringan) pada mata kuliah Asuhan Kebidanan yang berada pada kategori paling efektif adalah 72,3\% menggunakan media pembelajaran yang sesuai dan aspek yang kurang efektif adalah 19,4\% Aktivitas Pembelajaran Variatif

Tabel 3.

Distribusi Frekuensi Responden Berdasarkan Hasil Belajar Mahasiswa Pada Mata Kuliah Asuhan Kebidanan

\begin{tabular}{llll}
\hline No & Kategori & Frekuensi & Persentase (\%) \\
\hline 1. & Sangat baik & 15 & 41,7 \\
2. & Baik & 21 & 58,3 \\
\hline & Jumlah & 36 & 100 \\
\hline
\end{tabular}

Berdasarkan tabel diketahui bahwa Hasil Belajar Mahasiswa Pada Mata Kuliah
Asuhan Kebidanan $58,3 \%$ berada pada Kategori Baik

Tabel 4.

Hubungan Efektivitas Metode Pebelajaran Daring (Dalam Jaringan) terhadap Hasil Belajar Mahasiswa Pada Mata Kuliah Asuhan Kebidanan Di STIKes Payung Negeri Pekanbaru Tahun 2021

\begin{tabular}{|c|c|c|c|c|c|c|}
\hline \multirow{3}{*}{$\begin{array}{l}\text { Efektivitas metode } \\
\text { pemberian tugas }\end{array}$} & \multicolumn{6}{|c|}{ Hasil Belajar } \\
\hline & \multicolumn{2}{|c|}{ Sangat baik } & \multicolumn{2}{|c|}{ Baik } & \multicolumn{2}{|r|}{ Jumlah } \\
\hline & $\mathrm{N}$ & $\%$ & $\mathrm{~N}$ & $\%$ & $\mathrm{~N}$ & $\%$ \\
\hline Efektif & 12 & 57,1 & 9 & 42,9 & 21 & 100 \\
\hline Cukup efektif & 3 & 30 & 7 & 70 & 10 & 100 \\
\hline Kurang efektif & 0 & 0 & 5 & 100 & 5 & 100 \\
\hline \multirow[t]{3}{*}{ Sperman's rho } & \multicolumn{4}{|c|}{ Correlation Coefficient } & \multicolumn{2}{|r|}{$0,509 * *$} \\
\hline & \multicolumn{4}{|c|}{ Sig.(2 tailed) } & \multicolumn{2}{|r|}{0,00} \\
\hline & \multicolumn{3}{|c|}{$\mathrm{N}$} & & \multicolumn{2}{|r|}{36} \\
\hline
\end{tabular}


Dari tabel diketahui bahwa efektivitas metode pembelajaran Daring berada pada kategori efektif, 57,1\% menghasilkan hasil belajar yang sangat baik

Dari kuatnya hubungan, diketahui bahwa koefisien korelasi sebesar $\mathrm{r}=0,509$ termasuk pada kategori sedang (0,40-0,599), dimana semakin tinggi efektivitas metode pemberian tugas, maka semakin tinggi pula hasil evaluasi belajar mahasiswa

Berdasarkan hasil uji signifikansi koefisien korelasi didapatkan t hitung $=3,448$. Dengan $\mathrm{dk}=36-2=34$ dan $\alpha=0,05$, untuk tes dua sisi. Dalam tabel $\mathrm{t}$ didapatkan nilai $=3,448$. Dengan demikian $t$ hitung $(3,448)>t$ tabel (2,021). Maka dengan taraf signifikansi sebesar 5\% atau dengan taraf kepercayaan sebesar $95 \%$, terdapat hubungan yang signifikan antara efektivitas metode pembelajaran Daring dengan hasil belajar mahasiswa pada mata kuliah Asuhan Kebidanan.

\section{Pembahasan}

\section{a. Efektivitas Metode Pembelajaran Daring (Dalam Jaringan)}

Hasil penelitian menunjukkan efektivitas metode pembelajaran Daring (Dalam Jaringan) pada mata kuliah Asuhan Kebidanan 58,3\% berada pada kategori efektif. Dikatakan efektif ketika tujuan yang telah ditetapkan dapat tercapai. Metode pembelajaran online dikatakan efektif untuk menyampaikan materi pada mata kuliah Asuhan Kebidanan dilihat dari keberhasilan mahasiswa mencapai tujuan pembelajaran

Hasil penelitian juga menunjukkan bahwa berdasarkan penilaian mahasiswa, dalam pelaksanaan metode pembelajaran daring dosen sudah memperhatikan aspek-aspek seperti: menggunakan media pembelajaran yang sesuai, Strategi pembelajaran (Instructional Strategy) yang baik, Aktivitas pembelajaran yang variatif, dan Sumber Belajar (Learning Resources) yang luas. [15]

Dilihat dari penggunaan media pembelajaran yang merupakan alat untuk menyampaikan isi pembelajaran. Pemilihan media dalam pembelajaran Daring diharapkan sebagai alat bantu mengajar yang dapat merangsang mahasiswa untuk dapat meyerap materi dengan lebih efektif dan efisien. [17] Media pembelajaran Daring yang digunakan digunakan pada penelitian ini berupa aplikasi zoom meeting untuk pertemuan virtual, google classroom, edmodo, whatsapp group, modul dan video pembelajaran. Masing-masing media memiliki karakteristik, keuntungan dan kelemahan. Oleh karena itu media pembelajaran yang dirancang dengan baik akan sangat membantu mahasiswa dalam mencapai tujuan pembelajaran.

Aspek lain yang harus diperhatikan dalam metode pembelajaran Daring adalah Strategi pembelajaran (Instructional Strategy) yang baik. Pemilihan metode pembelajaran yang tidak didasari karakteristik peserta didik, tujuan pembelajaran, dan bahan ajar serta Penerapan pendekatan yang tidak berorientasi pada mahasiswa (student centered approach) tidak akan menghasilkan pencapaian tujuan pembeajaran [18] Pada penerapan metode pembelajaran Daring di STIKes Payung negeri dosen terlebih dahulu mempertimbangkan metode pembelajaran dan masalah yang dialami mahasiswa dalam proses belajar. Dalam penerapan strategi pembelajaran dosen harus memilih strategi penyampaian, urutan, dan pengelompokkan rumpun (cluster), komponen belajar yang dimasukan dalam pembelajaran, mengembangkan struktur pelajaran, dan menyeleksi media dalam menyampaikan pembelajaran[19]

Efektivitas pembelajaran daring juga dilihat dari aktivitas pembelajaran yang variatif yang diterapkan kepada mahasiswa. Aktivitas pembelajaran merupakan segala bentuk kegiatan dalam mengikuti pembelajaran. Aktivitas pembelajran yang diterapkan antara lain visual activities dengan memperhatikan 
presentasi dan membaca modul pembelajran, oral activities berupa diskusi kelompok dan Tanya jawab, serta listening activities berupa pertemuan virtual dengan menggunakan aplikasi zoom, writing activities dengan membuat resume dan laporan, dan mental emotional ectivities berupa keberanian menanggapi dan memecahkan masalah. [20]

Sumber Belajar (Learning Resources) yang luas, meliputi data, orang dan barang yang dapat dipergunakan oleh mahasiswa baik secara mandiri maupun kelompok, untuk memberikan kemudahan belajar harus juga diperhatikan. Sumber belajar yang dirancang oleh dosen (modul pembelajaran) maupun yang sudah tersedia (perpustakaan, internet) harus dapat dimanfaatkan mahasiswa untuk dapat membantu dan meningkatkan minat mahasiswa dalam belajar.

Efektivitas metode pembelajaran daring ini juga sesuai dengan penelitian yang dilakukan Mustakim (2020) dimana didapatkan hasil penilain pembelajaran matematika pada siswa dilakukan menggunakan media online $46,7 \%$ menilai efektif, dan $10 \%$ peserta didik yang menganggap pembelajaran daring tidak efektif. [21]

\section{b. Hasil Belajar Mahasiswa}

Berdasarkan hail penelitian diketahui bahwa 58,3\% hasil belajar mahasiswa pada mata kuliah asuhan kebidann berada pada kategori Baik. Hasil belajar ini diperoleh dari sistematika evaluasi hasil belajar yaitu $30 \%$ tugas (individu dan kelompok), 30\% softskill mahasiswa (keaktifan dan kemampuan berkomunikasi), 20\% (Ujian Tengah Semester) dan 20\% (Ujian Akhir Semester)

Hal ini menunjukkan bahwa materi yang disampaikan oleh dosen dengan metode pembelajaran daring menggunakan aplikasi zoom meeting untuk pertemuan virtual, diskusi dan materi perkuliahan menggunakan di Google classroom, edmodo, dan whatsapp group (WAG) dapat ditangkap dengan baik oleh mahasiswa. Selain itu, mahasiswa juga dapat mengerjakan tugas yang merupakan bagian dari penilaian hasil belajar dengan baik dan tepat waktu, sesuai dengan modul perkuliahan dan rancangan tugas yang diberikan dosen.

Hasil belajar sering kali menjadi faktor penting dalam tolak ukur keberhasilan pendidikan. Hal ini dikarenakan dengan melakukan evaluasi terhadap hasil belajar akan diketahui tingkat penguasaan peserta didik terhadap materi yang telah diberikan, kecakapan, motivasi, bakat dan minat serta sikap peserta didik dalam proses pembelejaran, tingkat kemajuan dan kesesuaian hasil belajar peserta didik dengan standar kompetensi dan kompetensi dasar yang dietapkan, mendiagnosis keunggulan dan kelemahan peserta didik [9].

Evaluasi pembelajaran merupakan suatu proses yang dilakukan untuk mengetahui tingkat kinerja akademik. Evaluasi hasil belajar dilakukan secara menyeluruh dan kontinyu dengan cara yang sesuai dengan ciri-ciri pendidikan yang diterapkan.

Dalam UU no.20 tahun 2003 tetang sistem pendidikan Nasional pasal 57 ayat 1 dijelaskan bahwa evaluasi dilakukan dalam rangka pengendalian mutu pendidikan kepada pihak-pihak yang berkepentingan. Ayat 2 menjelaskan, evaluasi dilakukan terhadap peserta didik, lembaga dan program pendidikan pada jalur formal dan nonformal untuk semua jenjang, satuan dan jenis pendidikan. [19]

Berdasarkan sistematika evaluasi hasil belajar yang ditetapkan di Program Studi Sarjana Kebidanan dan Profesi Bidan STIKes Payung Negeri Pekanbaru tersebut dalam metode pembelajaran Daring (Dalam Jaringan) diketahui bahwa sangat diperlukan aktivitas yang mendukung baik dari dosen selaku fasilitator pembelajaran maupun mahasiswa sebagai pelaksana aktif pembelajaran. Dalam pelaksanaan nya hasil belajar didapatkan dengan evaluasi diagnostic untuk mengetahui kelemahan mahasiswa dan memberikan perlakuan yang tepat, evaluasi formatif berupa penilaian dalam UTS dan UAS yang 
dilakukan secara Daring dengan menggunakan platform google classroom, google formulir, edmodo dan aplikasi zoom meeting. serta evaluasi sumatif dengan pemberian penugasan, dan kuis kepada mahasiswa yang dikumpulkan dan dinilai berdasarkan keaktifan dan penguasaan materi mahasiswa. [12]

Selain metode evaluasi hasil belajar yang diterapkan, terdapat factor-faktor lain yang akan mempengaruhi hasil belajar. Faktorfaktor tersebut meliputi pengetahuan, sikap dan keterampilan yang kesemuanya dipengaruhi oleh dua faktor yaitu: faktor intern, (yang berasal dari dalam diri individu tersebut), meliputi kemampuan, motivasi, ketekunan, keadaan sosial ekonomi, fisik dan psikis. Faktor ekstern (yang berasal dari luar diri individu), meliputi kurikulum, guru, fasilitas dan sumber daya yang diterima.[22]

Hasil belajar Baik (B) yng diperoleh mahasiswa tersebut juga didukung oleh penelitian yang dilakukan Hapsari,TN, Fitria.AS tahun 2020 melalui hasil UTS dan UAS yang dikerjakan oleh mahasiswa dikategorikan bahwa sebagian besar mahasiswa telah dapat memahami materi dengan baik yaitu sejumlah 54,3\% (51 orang) dari 92 responden memiliki hasil yang baik dan di atas rata-rata atau lulus, dan tidak ada satupun yeng mengulang mahasiswa juga merasa puas atas capaian nilai akhir di mata kuliah tersebut.[23]

c. Hubungan Efektivitas Metode Pembelajaran Daring dengan Hasil Belajar Mahasiswa pada Mata Kuliah Asuhan Kebidanan.

Hasil analisis data mengunakan statistik Rank Spearman, didapatkan koefisien korelasi (r) adalah 0,509 yang berarti terdapat hubungan positif antara efektivitas metode pembelajaran Daring (dalam Jaringan) dengan hasil belajar mahasiswa, dimana semakin efektif metode pembelajaran Daring semakin baik hasil belajar mahasiswa.

Korelasi tersebut menunjukkan hubungan yang sedang karena pada kisaran 0,40 0,599 . Dengan melakukan uji signifikansi koefisien korelasi dengan taraf signifikansi $5 \%$ atau dengan taraf kepercayaan sebesar 95\% terdapat hubungan yang signifikan antara efektivitas metode pembelajaran Daring dengan hasil belajar mahasiswa. [24]

Hasil penelitian ini juga sejalan dengan penelitian yang dilakukan oleh Hikmatiar dkk. (2020) yang menunjukkan bahwa terdapat dampak yang positif terhadap peningkatan hasil belajar motivasi serta minat dari siswa dengan menggunakan metode pembelajaran daring (google classroom) selain itu metode pembelajran daring juga dapat menumbuhkan sikap kreatif dari mahasiswa selaku peserta didik. [25]

Minat dan motivasi merupakan salah satu factor yang dapat mendukung mahasiswa untuk mencapai tujuan pembelajaran, sehingga berdampak terhadap hasil belajar mahasiswa. untuk dapat memotivasi mahsiswa baik secara intrinsik maupun ekstrinsik, metode pembelajaran Daring yang digunakan dalam proses pembelajaran harus memperhatikan kelebihan dan kekurangan dari metode daring. Hasil penelitian Puspitasari, P. (2018) mengungkapkan dalam menerapkan metode pembelajaran daring e-learning dosen harus mampu mendorong peserta didik untuk dapat berinteraksi, berdialog, bekerjasama dan juga berpartisipasi aktif, tidak hanya menjadi pendengar atau penonton saja, tapi dapat membangun pengetahuan bersama.[26]

Dalam penerapannya metode pembelajaran daring akan memberikan kemudahan dan pengalaman yang berbeda dibandingkan metode konvensional. Hal ini dikarenakan metode pebelajaran daring memberikan waktu yang lebih tepat dan fleksibel bagi peserta didik untuk dapat mengikuti proses belajar sesuai dengan kebutuhan mereka sehingga dapat menyerap lebih baik materi pembelajaran yang disampaikan.

Penelitian yang dilakukan oleh Khusniyah.NL dan Hakim (2019) juga menunjukkan bahwa pembelajaran Daring 
dengan menggunakan web blog memberikan perbedaan signifikan terhadap hasil belajar siswa dalam kemampuan siswa dalam memahami teks berbahasa Inggris, $P(T-t)$ two-tail (3.71) > t-table $(t$ Critical two-tail $)=1.99 .[27]$

\section{KESIMPULAN}

Metode pembelajaran daring yang efektif dengan memperhatikan aspek-aspek seperti: menggunakan media pembelajaran yang sesuai, Strategi pembelajaran (Instructional Strategy) yang baik, Aktivitas pembelajaran yang variatif, dan Sumber Belajar (Learning Resources) yang luas akan dapat mencapai tujuan pembelajaran dan menjadikan hasil belajar mahasiswa berada pada kategori Baik.

\section{DAFTAR PUSTAKA}

[1] Kemenkes RI, Pedoman Penyusunan Kurikulum Institusi Pendidikan Tenaga Kesehatan. Jakarta: Kemenkes RI, 2015.

[2] Kemenkes RI, Pedoman Penyelenggaraan Program Studi Profesi Bidan. Jakarta: Kemenkes RI, 2019.

[3] Firdaus, Dampak Covid-19 Terhadap Kebijakan Pendidikan Di Indonesia antara Idealisme dan Realitas. Yogyakarta: UAD Press, 2021.

[4] Pohan, Konsep Pembelajaran Daring Berbasis Pendekatan Ilmiah. Jawa Tengah: Sarnu Untung, 2020.

[5] Dirjen DikTI, Buku Pendidikan Tinggi Di Masa Pandemi Covid-19. Jakarta: Direktorat Jenderal Pendidikan Tinggi Kementerian Pendidikan dan Kebudayaan RI, 2020.

[6] Ratnanengsih, "pembelajaran daring partograf pada mata kuliah asuhan kebidanan persalinan masa pandemi," Intelektiva J. Ekon. Sos. Hum., vol. 2, no. 2, hal. 123-128, 2020.

[7] Sundayana, "Efektivitas Pembelajaran Online Pada Pendidikan Tinggi Kesehatan Di Masa Pandemi Covid19," Ganaya J. Ilmo Sos. dan Hum.,
Hasil penelitian Nadziroh (2017) juga menyatakan bahwa untuk dapat meningkatkan mutu pembelajaran metode daring (e-learning) dikatakan efekti karena peserta didik tidak hanya terpaku pada proses pembelajaran yang dilaksanakan pada satu waktu dan ruang saja.[28]

vol. 3, no. 2, hal. 433-440, 2020.

[8] Mahmudi, Manajemen Kinerja Sektor Publik. Yogyakarta: UPP AMP, 2005.

[9] Susanto, Teori Belajar dan Pembelajaran di Sekolah Dasar. Jakarta: Prenadamedia Group, 2016.

[10] Sani, Inovasi Pembelajaran. Jakarta: PT Bumi Aksara, 2015.

[11] Sulistijowati, Peningkatan Kualitas Pendidikan Tinggi Melalui Program Detasering. Sumatera Barat: Insan Cendekia Mandiri, 2021.

[12] Yuliani, Pembelajaran Daring Untuk Pendidikan: Teori dan Penerapan. Medan: Yayasan Kita Menulis, 2020.

[13] Thobroni, Belajar dan Pembelajaran Teori dan Praktik. Yogyakarta: Arruz Media, 2015.

[14] Mirdanda, Motivasi Berprestasi \& Disiplin Peserta Didik Serta Hubungannya Dengan Hasil Belajar. Kalimantan Barat: Yudha English Gallery, 2018.

[15] Magdalena, "Pengelolaan Pembelajaran Daring Yang Efektif Selama Pandemi Di SDN 1 Tanah Tinggi," J. Edukasi dan Sains, vol. 2, no. 2, hal. 366-377, 2020.

[16] Rusdiana, "Respon pada Pembelajaran Daring bagi Mahasiswa Mata Kuliah Pengantar Hukum Indonesia," J. Integr., vol. 3, no. 1, hal. 1-12, 2020.

[17] Hamid, Media Pembelajaran. Jakarta: Yayasan Kita Menulis, 2020.

[18] Henderson, Effective Teaching: Instructional Methods and Strategies For Occuptional Therapy Education. USA: Slack Incorporated, 2021.

[19] Dirjen Dikti, Strategi Pembelajaran dan Pemilihannya. Jakarta: Direktorat Jenderal Peningkatan Mutu Pendidikan dan Tenaga Kependidikan Departemen 
Pendidikan Nasional, 2008.

[20] Sadirman, Interaksi dan motivasi belajar mengajar. Jakarta: Raja Gravindo Persada, 2016.

[21] Mustakim, "Efektivitas Pembelajaran Daring Menggunakan Media Online Selama Pandemi Covid -19 Pada Mata Pelajaran Matematika," al asma J. Islam. Educ., vol. 2, no. 1, hal. 1-12, 2020.

[22] Purwanto, Prinsip-prinsip dan teknik evaluasi pengajaran. Bandung: PT.Remaja Rosdakarya, 2010.

[23] Hapsari, "Efektivitas Pembelajaran Daring Mata Kuliah Evaluasi Pengajaran Bahasa Dan Sastra Indonesia Masa Pandemi Covid-19," J. Ilm. Semant., vol. 2, no. 1, hal. 11-21, 2020.

[24] Sugiyono, Metode Penelitian Kuantitatif, Kualitatif dan $R \& D$. Bandung: CV. Alfabeta, 2013.

[25] Hikmatiar, "Pemanfaatan Learning Manegement System Berbasis Google Classroom Dalam Pembelajaran," $J$. Pendidik. Fis., vol. 8, no. 1, hal. 78-86, 2020.

[26] Puspitasari, "Pengaruh Penggunaan Media Pembelajaran terhadap Motivasi Belajar Mahasiswa IKIP Siliwangi," Parol. J. Pendidik. Bhs. Dan Sastra Indones., vol. 1, no. 2, hal. 227-232, 2018.

[27] Khusniyah, "Efektifitas pembelajaran berbasis daring: sebuah bukti pada pembelajaran bahasa inggris," J. tatsqif, vol. 17, no. 1, hal. 19-33, 2019.

[28] Nadziroh, "Analisa Efektifitas Sistem Pembelajaran Berbasis E-Learning," $J$. Ilmu Komput. Dan Desain Komun. Vis., vol. 2, no. 1, hal. 1-14, 2017. 